\title{
Effects of Low Temperatures on the Formation of Adaptive Reactions: A Review
}

\author{
Veronika P. Patrakeeva, PhD*; Elena E. Basova \\ Federal Center for Integrated Arctic Research of the Russian Academy of Science \\ Arkhangelsk, the Russian Federation
}

\begin{abstract}
The review presents the results of studies on the effect of low temperatures of different durations on the formation of adaptive reactions in humans. The mechanisms of changes in the metabolic and hormonal processes and cellular and humoral immune response are discussed.(International Journal of Biomedicine. 2018;8(2):95-101.)
\end{abstract}

Key Words: cold $\bullet$ adaptation $\bullet$ variability $\bullet$ stability $\bullet$ hypothermia $\bullet$ immunity $\bullet$ metabolism

\section{Basic Part}

The cold factor has a strong stress effect on the body. In natural conditions, the effect of low temperatures can be multiplied in combination with the wind regime, high humidity and vibration. The peculiarities of the reaction of the adaptive systems of the body to low temperatures are determined by the duration of the action (short-term or long-term) and individual sensitivity. Many works have been devoted to studying the health of the indigenous and nonindigenous residents of the North. The results of the studies by V. Kaznacheyev and colleagues testify to a change in all types of metabolism (proteins, fats, carbohydrates, vitamins, macro- and microelements) in native inhabitants of high latitudes. There is a switch from a carbohydrate to a lipid type of metabolism, enhancing lipid peroxidation (LPO) with the formation of the polar metabolic type. ${ }^{(1,2)}$ The effect of cold as a stress factor on the human body of newcomers is accompanied by a typical picture of the stress response with an increase in the neurotransmitters of the hypothalamus, pituitary hormones, and the adrenal cortex. ${ }^{(3,4)}$ At the same time, the concentration of these hormones in indigenous people is slightly higher than in people who live in milder climatic regions of Russia. This is due to the development of the so-called stress diabetes (i.e. a decrease in the blood insulin level, which plays the role of a

*Corresponding author: Veronika P. Patrakeeva, PhD. Head of the Department of Environmental Immunology, Federal Center for Integrated Arctic Research, the Russian Academy of Science. Arkhangelsk, Russia.Email: patrakeewa.veronika@yandex.ru counter-hormone in relation to glucocorticoids). ${ }^{(5)}$ In addition, physical activity at low temperatures also contributes to an increase in the level of catecholamines and glucocorticides, which must be taken into account since work in the open air is often shift work. L.Kapilevich and S.Krivoshchekov have shown that individuals differ in the direction of the shifts in systemic physiological responses to the cold, depending on the functional reserves and the level of energy expenditure of the body ${ }^{(6)}$ At the same time, in newcomers, especially those working on a shift method, it is possible to attribute the state of "unfinished adaptation" to disturbances in the intersystem coordination of functions. These disturbances result in a depletion of existing reserves in the form of reduced ventilation function of the lungs, reduced adaptive reserve of the circulatory system, the predominance of sympathetic tone of the autonomic nervous system, and an imbalance in thyroid hormones. ${ }^{(6-9)}$ In cold-adapted people, as a mechanism for reducing heat loss, the core temperature of the body decreases by reducing the average skin temperature and changing the temperature sensitivity of the central hypothalamic thermoreceptors (sat point). The functioning of any body system requires a large expenditure of energy (ATP), so energy homeostasis is crucial in the process of successful adaptation to any changes in the environment. The transition to lipid metabolism in cold conditions contributes to the formation of a large amount of energy consumed both for heating the body and for performing the functions that provide the body's homeostasis. ${ }^{(10)}$ However, the intensification of lipid metabolism is one of the factors in the development of hypoxia, since in this type of metabolism the need for 
oxygen in tissues significantly increases. A decrease in the content of tocopherol and an increase in the content of LPO products (diene conjugates) and lyso-form phospholipids promote the formation of protein-lipid crosslinks in the erythrocyte membrane, which leads to an increase in the viscosity of membranes. In addition, cortisol, interacting with erythrocytes, also increases their microviscosity. ${ }^{(11)}$ Accumulation in the blood of products of peroxidation creates oxidative stress and can cause destruction of cell membranes of erythrocytes (hypochromia, anisocytosis), as well as the relative neutropenia and reduction in the level of segmented neutrophils, etc. ${ }^{(12)}$ Another factor determining the development of tissue hypoxia is bronchospasm in breathing cold air, which also contributes to the formation of polar dyspnea, or circumpolar hypoxic syndrome. ${ }^{(13)}$ As a result of long-term immunological monitoring of the inhabitants of the northern territories, researchers have found that the character of the reactive shifts in the inhabitants of the north to various adverse factors is one type at the beginning and includes the activation of the immune system. Next, another type of shift occurs in which the prolonged activation reduces reserve capacity, which is manifested by a decrease in the content of functionally active mature Tlymphocytes. Further, a persistent decrease in the blood levels of functionally active phenotypes of T-lymphocytes is formed, which is compensated by an increase in the number of the total pool of circulating lymphocytes, lymphoproliferative reactions, proliferative monocyte reactions, and activation of phagocytosis intensity. ${ }^{(14-18)}$

Despite the fact that the impact of cold determines a variety of adaptive shifts in the neuroendocrine system, with an increase in the concentration of catecholamines, corticosteroids, histamine and $\beta$-endorphin, ${ }^{(19-23)}$ many researchers agree that cold is primarily a catecholamine stress associated with an increase in the level of norepinephrine and adrenaline in blood, and is initiated along the axis hypothalamuspituitary gland-adrenal glands. ${ }^{(24-32)}$ Catecholamines exert their regulatory influence through adrenoceptors located on virtually all cells of the body. It is known that the thermogenic effect of norepinephrine is realized through the activation of $\beta$-adrenergic receptors due to the enhancement of noncontractile thermogenesis and heat production. ${ }^{(33,34)}$ Ionophoretic introduction of norepinephrine into the skin, where the thermoreceptors are concentrated, leads to a decrease in the temperature thresholds of the cold-protective reactions. On the 30th day of cold adaptation, under the influence of adrenaline, the pressor action on arteries increases and the systemic pressure decreases, which contributes to the preservation of heat and the redistribution of blood flow from the surface vessels into core of the body. ${ }^{(35)}$ After 10 days of cold adaptation, the reactivity of the systemic pressure decreases equally for norepinephrine and epinephrine by more than 2 times. ${ }^{(3)}$ Depending on the duration of exposure to cold, the number of the active $\alpha 1$-ARs ( $\alpha 1$-adrenergic receptors) is changed in the musculoskeletal area. So, after a single cooling, the number of these receptors increases almost twofold, and on the 30th day of cold adaptation the sensitivity of $\alpha 1$-ARs is normalized and the number of active $\alpha 1$-APs is about $10 \%$ lower than those in the control group. ${ }^{(37)}$
Activation of catecholamines occurs with the participation of $\mathrm{Ca}^{2+}$, which enters the cell or in the endings of the sympathetic nervous system. In addition, calcium ions participate in the mechanisms that activate processes aimed at maintaining the body's temperature homeostasis and that accelerate the development of the vascular response to heating through the heat-sensitive ion channel TRPV1, which determines the modality of the temperature signal and the direction of the effector reactions. ${ }^{(38)}$ The effect of low temperaturesis mediated through cold-sensitive TRPion channels. ${ }^{(39,40)}$ They are sufficiently well studied and are represented by two channels, TRPA1 and TRPM8. ${ }^{(41-43)}$ T.Kozyreva and colleagues ${ }^{(44)}$ showed that TRPM8 takes part in the modulation of the immune response. Thus, the pharmacological activation of the TRPM8 ion channel with menthol, without changing the temperature, leads to an increase in the content of IL- 6 and IL- $1 \beta$, a significant increase in the antigen-binding properties of spleen cells, and a decrease in the blood level of IgG. ${ }^{(44)}$ It has been found that the preliminary activation of the TRPM8 ion channel with menthol weakens the depressing effect of subsequent deep cooling on the immune response. ${ }^{(45)}$

It is also assumed that there is a genetic predisposition to cold adaptation. Scientists of the University of Cambridge (2013) discovered genes responsible for survival in cold conditions: the UCP1 gene encodes a dissociating protein, which is responsible for adaptation to cold and for heat generation; the ENPP7 gene encodes an enzyme involved in intestinal digestion, which allows one to consume fatty foods without significantly increasing the level of the atherogenic lipid fraction; the PRKG1 gene encodes an enzyme that activates the contraction of the smooth muscle of blood vessels.

According to a study by G.Beloborodov, ${ }^{(46)}$ under the influence of a strong cold stimulus eosinocytosis develops. This condition is associated with the increased formation of histamine in the skin in the first minutes of irritation. An increased amount of eosinophils absorbs and cleaves histamine. In the following minutes, the amount of eosinophils decreases and the vasodilator effect of histamine is manifested - severe skin hyperemia. Temperature conditions also change the response of the body to agonists and antagonists of serotonin. ${ }^{(47,48)}$ A number of authors suggest as the temperature changes, the state of serotonin receptors changes, or, conversely, under the influence of serotonin receptors, changes occur in the sensitivity and/(or) the functions of temperature-controlling neurons. ${ }^{(49)}$

The acute cold effect, in contrast to the chronic one, leads to depletion of the body's adaptive reserves, primarily energy reserves, to a decrease in tissue metabolism, and to the formation of proliferative-dystrophic and trophic disorders in all organs. ${ }^{(50-52)}$ The main sources of energy in the cell are mitochondria; under the influence of low temperatures, in mitochondria the intensity of oxidation of succinic acid is inhibited, ${ }^{(53)}$ and consequently, the formation of ATP decreases, resulting in a drastic decrease in the contractile activity of all muscles. ${ }^{(54)}$ The main bioenergetic mechanism for increasing the organism's resistance to cooling is the enhancement of free oxidation and a decrease in the proportion of phosphorylating 
oxidation in mitochondria of thermogenic tissues. ${ }^{(55)}$ In turn, the mechanisms of dissociation of oxidative phosphorylation and activation of free oxidation, providing thermogenesis, are controlled by a system of calcium homeostasis. ${ }^{(56,57)}$ The impact of a strong stress factor leads to a decrease in the calciumtransport function of mitochondria, as a result of which the energy deficit of cells and tissues increases. ${ }^{(58)}$

It is well known that low temperatures contribute to reduction of skin microcirculation, redistribution of blood flow, and reduction of systolic pressure. ${ }^{(59-61)}$ The positive effect of cold on the functional state of the central nervous system is due to its ability to modulate the temperature homeostasis. ${ }^{(62,63)}$ van Marken Lichtenbelt and colleagues ${ }^{(64)}$ revealed a negative correlation between the mean skin temperature and the level of cognitive activity. There are data on gender differences in response to cryogenic training conducted in a closed air sauna with preliminary adaptation of patients to cold air in the prechamber at $\mathrm{t}=-30 \pm 5^{\circ} \mathrm{C}$ for 30 seconds followed by cooling in the main chamber at $\mathrm{t}=-110 \pm 5^{\circ} \mathrm{C}$ for $2.5-3$ minutes. It was found that such loads have a more positive effect of on the bodies of men than of women, which was manifested in a decrease in the overall level of psychoemotional stress. ${ }^{(65)}$

Changes in metabolism directly affect the state of cell membranes/energy balance and this applies to all cells of the body, including immunocompetent ones. The results of investigations of the cold effect on immunological reactivity are very ambiguous. A great deal of research has been carried out on the therapeutic effects of cold, in particular, cryosauna. For example, good positive results are recorded in the treatment of such diseases as psoriasis, bronchial asthma, and rheumatoid arthritis. ${ }^{(66-69)}$ With the air cryotherapy technique, the blood levels of pro-inflammatory cytokines (IL-1, IL6, TNF $\alpha$ ) and circulating immune complexes decrease, the content of lysosomal proteins in neutrophils increases, and IgA concentration increases, as does the number of mature T-lymphocytes, the CD4/CD8 ratio, and the production of anti-inflammatory cytokines. ${ }^{(69)}$ At the same time, lower temperatures significantly reduce the greater number of proinflammatory cytokines. ${ }^{(70)}$ The positive effect is explained by the fact that cryotherapy promotes the outflow of lymph from the tissues, limiting vascular edema, improving the microcirculation of arterial and venous blood flow, reducing muscle tone, and stimulating regeneration. ${ }^{(71)}$

According to a study by V.Khasnulin, low temperatures reduce the quantitative and qualitative indices of cellular immunity with a $10 \%-15 \%$ reduction in the number of T-helpers and T-suppressors and a general decrease in the functional activity of T-lymphocytes. ${ }^{(72)}$ V.Nikolaev and colleagues ${ }^{(73)}$ found that adapting rats to cold is also accompanied by weakening of cellular immunity and nonspecific adaptive reactions, and the degree of expression of such changes depends on the length of stay in conditions of low temperatures. Depending on the adaptability of animals, the response rate to cold factor, estimated by the blood LPO level (intermediate products), changes (in adapted animals on the 30th minute of cold exposure, in unadapted animals on the 15th minute). ${ }^{(74)}$ Similar results were obtained by cooling laboratory mice for 3 hours at a temperature of $+7 /+8^{\circ} \mathrm{C}$, and the reaction of humoral and cellular immunity was suppressed. ${ }^{(75)}$ In another experimental study, it was shown that hypothermal action $\left(5 \mathrm{sec}\right.$ at $+7 /+9^{\circ} \mathrm{C}$ for 5 days $)$ promotes an increase in the thymus index and the level of lymphocytes in the bone marrow, a decrease in the absorption activity of phagocytes, an activation of the phagocyte metabolic activity and cellular immunity, and a suppression of humoral immunity. ${ }^{(76)}$ It was shown that the systemic effect of low temperatures inhibits synthetic nuclear processes in macrophages, reduces their absorbing activity, and reduces the number of leukocytes, erythrocytes and monocytes, with an increase in the activity of cellular immunity. ${ }^{(69,77)}$

During an experiment with laboratory mice with local cooling $+8^{\circ} \mathrm{C}$ for $5 \mathrm{sec}$, the researchers also noted an increase in the thymus index, the number of leukocytes in the peripheral blood, the metabolic activity of macrophages, and a nearly twofold increase in the functional activity of cellular immunity (the level of delayed-type hypersensitivity reaction was $26.2 \pm 1.3 \%$ and $57.6 \pm 4.3 \%$ in the control and experiment, respectively). ${ }^{(78)}$ Cooling causes degranulation of tissue basophils and edema of the dermis under the action of mediators, which leads to tissue infiltration by mononuclear cells, neutrophils, and eosinophils, and damage to the endothelium with the deposition of immune complexes and the development of necrotizing vasculitis. ${ }^{(79)}$ The effect of cold factor for one day causes a decrease in the granularity of mast cells, expanding lymphatic vessels and capillaries and loosening the basal membrane, and an increase in the size of endothelial cells. ${ }^{(80,81)}$ Under the influence of a single 3-minute exposure at $-20^{\circ} \mathrm{C}$, the mice showed a decrease in the serum levels of IL-2 IL-3, IL-5, and IL-10. ${ }^{(82)}$ In a study of the immune system in those affected by cold trauma, deficiency of T-lymphocytes was already determined in 4-8 days. In the first days after the cold stress, the number of B-lymphocytes was within the lower limit of the norm, with a subsequent slow decrease. The increase in the number of $\mathrm{T}$ and $\mathrm{B}$ lymphocytes begins from 18-21 days during frostbites of III-IV degree. ${ }^{\left({ }^{83}\right)}$ It was found that in the early period of frostbites, the reactions of cellular immunity, including macrophages and lymphocytes, prevail and the production of pro-inflammatory cytokines (IL$1 \beta$, TNF $\alpha$, IL-6, IL-8) increases. ${ }^{(84)}$ The level of IL-18 in the blood increases slightly, but its concentration in the bubble fluid during frostbites exceeds the concentration in the total blood flow by more than 2 times. ${ }^{(85)}$ Cases of cold trauma exhibit immunity disorders, which are expressed as a decrease in the absolute number of T-lymphocytes, T-helpers, T helper/T suppressor ratio, the concentration of $\mathrm{Clq}$, and $\mathrm{C} 3$ components of the complement system; and as an increase in the level of $\operatorname{IgA}, \operatorname{IgM}, \mathrm{C}$-reactive protein, $\alpha 1$-antitrypsin, $\alpha 2$-macroglobulin, orosomucoid, prealbumin, and transferrin. ${ }^{(86)}$

During the development of inflammatory reaction in deep frostbite, thrombus formation is activated in the damage zone, the content of cytokines and leukocytes in the blood increases, and the processes of repair and neoangiogenesis are triggered. ${ }^{(87)}$ During deep hypothermia, angiogenesis is restored slightly and the content of mast cells increases. ${ }^{(88)}$ Persons undergoing fatal hypothermia display a high content of reticulocytes (by 9.5\%) and plasmocytes (by 23.9\%) in the lymphoid tissue of the upper respiratory tract, while the levels 
of fibroblasts, lymphocytes, macrophages and cells in mitosis are reduced. ${ }^{(89)}$ Patients with local cold trauma of the lower limbs exhibit a decrease in the intensity, speed, and potential of platelet aggregation.

It is known that lymphocytes do not contain an actomyosin complex and are unable to independently pass through a damaged vascular wall into tissues to participate in cellular and humoral immunity. ${ }^{(90,91)}$ Platelets provide contact of lymphocytes and collagen fibers, and as a result, facilitate the migration of lymphocytes through the damaged wall of blood vessels deep into the injured area. ${ }^{(92)}$ In the early reactive period of local cold trauma, the leukocyte tissue factor (TF) expression increases, then decreases with recovery, but remains higher than that of healthy individuals. ${ }^{(93)}$ Activation of TF is inevitably accompanied by an increase in the level of atrombogenic factors of the endothelium and other cells, including TFPI. K.Golokhvast ${ }^{(94)}$ studied macrophages and lymphocytes of bronchoalveolar lavage in white mongrel rats after cooling in a climatic chamber at a temperature of $-15^{\circ} \mathrm{C}$ for 15 minutes. After the experiment, the number of viable cells decreased from $88.2 \%$ to $61 \%$, the ratio of macrophages/ lymphocytes changed from $30 \%$ to $70 \%$. Inverting the pool of macrophages and lymphocytes can be explained not by the death of macrophages, but by the increase in the pool of lymphocytes; accordingly, the inhibitory function of macrophages falls due to a decrease in their synthetic activity.

Moreover, low temperatures have a direct effect on the induction of lymphocyte apoptosis. When lymphocytic suspension is cooled $\left(-18-21^{\circ} \mathrm{C}\right)$, the morphological signs of apoptosis are observed 2-3 hours after stimulation, which is manifested in a decrease in the size of the cell and the appearance of apoptotic bodies. In such a case, the frequency of recording lymphocyte apoptosis directly depends on the temperature and the duration of exposure. ${ }^{(95)}$ However, in the presence of pathology, for example in patients with cold urticaria, a decrease was shown in the number of T-helpers and cytotoxic lymphocytes, expressing the marker of apoptosis, the absolute amount of $\mathrm{CD} 3+\mathrm{T}$-lymphocytes, and regulatory CD4+CD25+high T-lymphocytes. ${ }^{(96,97)}$

Thus, as can be seen from the presented data, studying the effect of low temperatures on the body does not lose its relevance and many questions of regulatory aspects are still unresolved. The reactivity of the regulatory systems providing homeostasis varies depending on the level of adaptation, genetic characteristics, and the strength and duration of influence of cold factor.

\section{Competing interests}

The authors declare that they have no competing interests.

\section{References}

1. Kaznacheev VP, Kaznacheev SV, Mayansky DN, Shorin YuP, Lepelleuoto Yu., Kim LB, et al. Clinical aspects of polar medicine. Moscow: Academy of Medical Sciences; 1986. [In Russian].
2. Kaznacheev VP. Modern aspects of adaptation. Novosibirsk: Nauka; 1980. [In Russian].

3. Afanasyeva RF, Burmistrov OV. [Cold stress and its prevention]. Occupational Medicine and Industrial Ecology. 2001;(8):7-9. [Article in Russian].

4. Limits of physiological fluctuations in metabolites, hormones, lymphocytes, cytokines and immunoglobulins in the peripheral blood among residents of the Arkhangelsk region (Information materials). Dobrodeeva LK, editor. Arkhangelsk; 2005.

5. Panin LE. Biochemical mechanisms of stress. Novosibirsk: Nauka; 1983. [In Russian].

6. Kapilevich LV, Krivoshchekov SG. Disorders in the Functional state of the body in shift workers and its correction under the conditions of the North. Hum Physiol. 2016;42(2):187-194.

7. Agadzhanian NA, Georgieva SA, Gladilin GP. [Effect of the shift and expedition-shift methods of labor activity on the hemostatic function of the body]. Fiziol Cheloveka. 1997;23(5):103-7.[Article in Russian]

8. Krivoschekov SG, Leutin VP, Chukhrova MG. Psychophysiological aspects of unfinished adaptation. Novosibirsk: SB RAMS; 1998. [In Russian].

9. Hasnulin VI. Introduction to polar medicine. Novosibirsk: SB RAMS; 1998. [In Russian].

10. Panin LE. [Homeostasis and problems of circumpolar health (methodological aspects of adaptation)]. Bull SB RAMS. 2010;30(3):6-11. [Article in Russian].

11. Panin LE. [Man in the extreme conditions in the Arctic]. Bull SB RAMS. 2010; 30(3):92-98. [Article in Russian].

12. Krivoshekov SG. [Work and human health in the Arctic]. Journal of Medical and Biological Research. 2016;(4):84-93. [Article in Russian].

13. Avtsyn AP, Zhavoronkov AA, Marachev AG, Milovanov A.P. The Pathology of Man in the North. Moscow: Meditsina; 1985. [In Russian].

14. Dobrodeeva LK, Zhilina L.P. Immunological reactivity and health status of the population of the Arkhangelsk region. Ekaterinburg: UrB RAS; 2008. [In Russian].

15. Dobrodeeva LK, Senkova LV. [The state of the human immune system in the North]. Proceedings of the All-Russia Scientific and Practical Conference with international participation "Problems of Human Ecology". Moscow; 2000: 69-76. [Article in Russian].

16. Repina VP. [Proliferative activity of blood cells in residents of the Nenets Autonomous Okrug]. Human Ecology. 2010;(5):51-54. [Article in Russian].

17. Poletaeva AV, Morozova OS. [Features of immunological protection and the content of cortisol in humans in the North]. Human Ecology. 2010;(5):42-45. [Article in Russian].

18. Patrakeeva VP. [Cytokine regulation of proliferative activity of peripheral blood cells]. Human Ecology. 2015;(12):28-33. [Article in Russian].

19. Kozyreva TV. Central and peripheral thermoreceptors. Comparative analysis of the effects of prolonged adaptation to cold and noradrenaline. Neurosci Behav Physiol. 2007;37(2):191-8.

20. Zhai H, Frisch S, Pelosi A, Neibart S, Maibach HI. Antipruritic and thermal sensation effects of hydrocortisone creams in human skin. Skin Pharmacol Appl Skin Physiol. 2000;13(6):352-7.

21. Cabot PJ. Immune-derived opioids and peripheral antinociception. Clin Exp Pharmacol Physiol. 2001;28(3):230-2. 
22. Grossmann M, Jamieson MJ, Kirch W. Histamine response and local cooling in the human skin: involvement of H1- and H2-receptors. Br J Clin Pharmacol. 1999;48(2):216-22.

23. Repina VP. [Influence of catecholamines on the level of immunoglobulins and cytokines in the blood]. Russian Allergology Journal. 2008;(S1):242-3. [Article in Russian].

24. Agadzhanyan NA, Bykov AT, Medalayeva RKh. [Physiological and therapeutic aspects of extreme general air cryogenic influences]. Ekologiya Cheloveka. 2012;(2):15-21. [Article in Russian].

25. Eliseev DN. Factors of physical nature in the complex treatment of patients with ischemic heart disease and hypertension. Abstract of ScD Thesis. Rostov-on-Don; 2007. [In Russian].

26. Fricke L, Fricke R, Wiegelmann L. [Beeinflussung hormoneller Reaktionen durch Ganzkörperkältetherapie]. Z Phys Med Bal Med Klim. 1988;17:363-364. [Article in German].

27. Leppaluoto J, Korhonen I, Hassi J. Habituation of thermal sensations, skin temperatures, and norepinephrine in men exposed in cold air. J Appl Physiol. 2001;90(4):1211-8.

28. Stratz T, Schlege P, Mennet P. e.u. Biochemische und hormonelle Reaktionen unter der Ganzkörperkältetherapie. In: Müller W, editor. Generalisierte Tendomyopathie Steinkopff. Darmstadt; 1991:299-306. [In German].

29. Zagrobelny Z, Halawa B, Jezierski C, Wawrowska A. [Effect of a single cooling of the entire body in the cryogenic chamber on selected hemodynamic parameters and blood serum hormone levels in healthy subjects]. Pol Tyg Lek. 1993;48(14-15):303-5. [Article in Polish].

30. Gurin VN. Thermoregulation and sympathetic nervous system. Minsk: Nauka i Technika; 1989. [In Russian].

31. Depocas F, Behrens WA. Levels of noradrenaline in plasma during thermogenesis induced by cold-exposure or by noradrenaline infusion in warm- and cold-acclimated rats. In: Girardier L, Seydoux J, editors. Effectors of thermogenesis. Basel, Switzerland: Karger; 1978:135-146.

32. Deryapa NR, Ryabinin IF. Adaptation of Man in the Polar Regions of the Earth. L.: Meditsina; 1977. [In Russian].

33. Kozyreva TV, Tkachenko EIa, Gonsales EV. [Effect of alpha2-adrenergic receptor antagonist yohimbine on thermoregulatory responses to cooling]. Ross Fiziol Zh Im I M Sechenova. 2012;98(8):1008-15.[Article in Russian].

34. Jansky L. Humoral thermogenesis and its role in maintaining energy balance. Physiol Rev. 1995;75(2):237-59. 35. Afanasyeva RF, Burmistrova OV, Bobrov AF. [Cold, criteria for assessing and predicting the risk of human cooling]. Bulletin of the East Siberian Scientific Center SBRAMS. 2006;(3):13-18. [Article in Russian].

36. Anan'ev VN. [Analysis of the reactivity of norepinephrine with adrenaline to systemic pressure after 10 days of adaptation to cold]. Fundamental Research. 2011;(10-1):13-16. [Article in Russian].

37. Anan'ev VN, Anan'eva OV, Miryuk MN, Pavlov NB, Ippolitov IV, Anan'ev GV, et al. [Adrenoreactivity of the arteries of the intestine and hind limb when adapting to the cold]. Vestnik RUDN, Seriia "Meditsina". 2009;(4):601-2. [Article in Russian].

38. Tkachenko EYa, Khramova GM, Kozyreva TV. Calcium ions facilitate body heat emission response to warming. Bull Exp Biol Med. 2015;158(3):291-4. doi: 10.1007/s10517-015-2743-x.

39. Caterina MJ. Transient receptor potential ion channels as participants in thermosensation and thermoregulation. Am J
Physiol Regul Integr Comp Physiol. 2007;292(1):R64-76. 40. Vay L, Gu Ch, McNaughton PA. The thermo-TRP ion channel family: properties and therapeutic implications. $\mathrm{Br}$ J Pharmacol. 2012;165(4):787-801. doi: 10.1111/j.14765381.2011.01601.x.

41. McKemy DD. How cold is it? TRPM8 and TRPA1 in the molecular logic of cold. Mol Pain. 2005;1:16.

42. Sabnis AC, Shadid M, Yost GS, Reilly CA. Human lung epithelial cells express a functional cold-sensing TRPM8 variant. Am J Respir Cell Mol Biol. 2008;39(4):466-74. doi: 10.1165/rcmb.2007-0440OC.

43. Li M1, Li Q, Yang G, Kolosov VP, Perelman JM, Zhou $\mathrm{XD}$. Cold temperature induces musin hypersecretion from normal human bronchial epithelial cells in vitro through a transient receptor potential melastatin 8 (TRPM8)-mediated mechanism. J Allergy Clin Immunol. 2011;128(3):626-34. e1-5. doi: 10.1016/j.jaci.2011.04.032.

44. Kozyreva TV. Participation of cold sensitive TRPM8 ion channel in modulation of metabolism and immune response. Frontiers. 2013. Available from: https:/www.frontiersin. org/10.3389/conf.fimmu.2013.02.00951/event_abstract

45. Kozyreva TV, Voronova IP. [Involvement of neurogenomic regulation in the maintenance of temperature homeostasis in the cold]. Russian Journal of Genetics: Applied Research. 2015;5(6):569-576.

46. Beloborodov GS, Beloborodov AG. [Evolutionary aspects of studying body hardening in the Far North-East of Russia]. In the collection: "Theoretical problems of theology and evolution". The Reading to the Memory of Prof. A.A. Lyubishchev. Institute of Ecology of the Volga river basin of the Russian Academy of Sciences. 2000:26-31.

47. Popova NK, Konusova AV. Brain and peripheral effects of serotonin on thermoregulation. Biogenic Amines. $1985 ; 3(2): 125-134$.

48. Oerther S. Temperature set-point changes induced by DA D2/3 and 5-HT1A receptor agonists in the rat. Neuroreport. 2000;11(18):3949-51.

49. Nicholas AC, Seiden LS. Ambient temperature influences core body temperature response in rat lines bred for differences in sensitivity to 8-hydroxy-dipropylaminotetralin. J Pharmacol Exp Ther. 2003;305(1):368-74.

50. Ivanov KP. Fundamentals of the energy of the body: Theoretical and practical aspects. Volume 1. General energy, heat exchange and thermoregulation. L.: Nauka; 1990. [In Russian].

51. Preobrazhenskaya V. Oxidation and phosphorylation in mitochondria of myocardium and skeletal muscles of white rats with cold exposure. Abstract of $\mathrm{PhD}$ Thesis. Yerevan; 1990. [In Russian].

52. Khaskin VV. Energy of heat formation and adaptation to cold. Novosibirsk: Nauka; 1975. [In Russian].

53. Urakov AL. [Suppression of antianginal preparations of oxidation of endogenous succinic acid]. Kardiologiia. 1981;(1):108.[Article in Russian].

54. Urakov AL. [Cold in the defense of the heart]. Uspekhi Sovremennogo Estestvoznaniia. 2013;(11):32-36. [Article in Russian].

55. Ivanov KP. [Modern medical problems of energy exchange in humans]. CyberLeninka. 2013. Available from: https://cyberleninka.ru/article/n/sovremennye-meditsinskieproblemy-energoobmena-u-cheloveka.

56. Parsons DS. Biological membranes: Twelve essays on their organization, properties, and functions. Clarendon Press: 
Oxford University Press, London; 1975.

57. Akopova OV, Nosar VI, Mankovskaya IN, Sagach VF. Calcium uptake in rat liver mitochondria accompanied by activation of ATP-dependent potassium channel. Biochemistry (Mosc).2008;73(10):1146-53..

58. Ivanov KP. Fundamentals of the energy of the body. Volume 5. Energy of the living world. Physiological problems. L.: Nauka; 2007. [In Russian].

59. De Paepe K, Houben E, Adam R. Hachem JP, Roseeuw D, Rogiers V. Seasonal effects on the nasolabial skin condition. Skin Pharmacol Physiol. 2009;22(1):8-14. doi: $10.1159 / 000159772$

60. Gerasimova LI. [Reinforced cold-induced vasoconstriction (Raynaud phenomenon) as a sign of emergency regulation of body functions under adaptation to cold]. Regional Haemodynamics and Microcirculation. 2007;21(1):40-42. [Article in Russian].

61. Freccero C, Wollmer P, Sundkvist G, Svensson H. The influence of wavelength and probe configuration on findings of a skin vasoconstriction test when using laser Doppler perfusion devices. Microvasc Res. 2006;71(1):64-7.

62. Agadzhanyan NA, BykovAT, Medalayeva RKh. [Problems of cryotherapy and the state of the psychoemotional sphere]. Journal of New Medical Technologies. 2010;17(3):129-133. [Article in Russian].

63. Portnov VV. General and local air cryotherapy. Collection of articles and manuals for doctors. 2nd ed. Moscow; 2016. [In Russian].

64. van Marken Lichtenbelt WD, Daanen HA, Wouters L, Fronczek R, Raymann RJ, Severens NM, Van Someren EJ. Evaluation of wireless determination of skin temperature using iButtons. Physiology \& Behavior. 2006;88(4-5):489-97.

65. Medalayeva RKh. [Gender peculiarities of central nervous system reactions to extreme cold of air cryosauna]. News of the Kabardino-Balkarian Scientific Center of $R A S$. 2013;53(3):176-180. [Article in Russian].

66. Fricke R. Ganzkörperkältetherapie in einer Kältekammer mit Temperaturen um $-110^{\circ} \mathrm{C}$. Z Phys Med Baln Med Klim. 1989;18(1):1-10. [Article in German].

67. Antonova VO. [Features of thermoregulation in persons exposed to extreme cryotherapy]. Pitaniia Eksp Klin Med. 2009;13(2):11-17. [Article in Ukrainian].

68. Portnov VV, Medalayeva RKh. Cryotherapy. In: Ponomarenko GN, editor. Physiotherapy. Moscow; 2009. [In Russian].

69. Karpova AV, Vasenova VYu, Butov YuS. [Influence of cryotherapy in the complex treatment of psoriasis on immunological indices and clinical results]. Bulletin of Russian State Medical University 2010;(2):67-71. [Article in Russian].

70. Sliwiński Z, Kufel W, Michalak B, Halat B, Kiebzak W, Wilk M, Jonak R. The assessment of pelvic statics in patients with spinal overload syndrome treated in whole-body cryotherapy. Ortop Traumatol Rehabil. 2005;7(2):218-22.

71. Baranov AYu, Kovalenko IM, Yatmanov AN. [On the multilateral study of changes in the body of a healthy person in response to cryotherapy]. Bulletin St. Petersburg Medical University I.I.Mechnikov. 2005;6(2):147-50. [Article in Russian].

72. Khasnulin VI. Introduction to polar medicine. Novosibirsk: Izdatel'stvo SB RAMS;1998. [In Russian]. 73. Nikolaev VM, Semenova KE, Naumova YaI, Vladimirov LN, Golderova AS, Kuzmina SS, Fedorova SA. [Functional activity of blood leukocytes and nonspecific adaptive reaction of rats to cold]. Veterinariia. 2016;1:44-46. [Article in Russian].

74. Pozdnyakova ON, Proshina LA, Kondratenko EI, Pozdnyakov OG. [Early changes in the level of products of lipid peroxidation in blood in rats adapted and unadapted to the cold]. Vestnik of Astrakhan State Technical University. 2006;(3):207-13. [Article in Russian].

75. Arzhakova LI. Influence of adaptogens on the functional activity of cells of the immune and hematopoietic systems during cold exposure. Abstract of PhD Thesis. Novosibirsk; 2000. [in Russian].

76. Fisher TA. Influence of the dosed temperature influence on the immunophysiological mechanisms in the experiment. Abstract of PhD Thesis. Tyumen; 2007. [In Russian].

77. Mayansky DN. Chronic inflammation. M.: Meditsina, 1991. [In Russian].

78. Kalenova LF, Suhovei YuG, Novikova MA, Fisher TA. [Influence of the local effect of the temperature factor on the immunophysiological parameters of the body in the experiment]. Journal of New Medical Technologies. 2009;16(4):21-24. [Article in Russian].

79. Soter NA, Lewis RA, Corey EJ, Austen KF. Local effects of synthetic leukotrienes (LTC4, LTD4, LTE4, and LTB4) in human skin. J Invest Dermatol. 1983;80(2):115-9.

80. Prokhorov SN. Hypothermia in aortic coarctation surgery. Abstract of PhD Thesis. Novosibirsk; 2004. [In Russian].

81. Crandall CG, Meyer DM, Davis SL, Dellaria SM. Palmar skin blood flow and temperature responses throughout endoscopic sympathectomy. Anesth Analg. 2005;100(1):277-83.

82. Trunova GV, Makarova OV, Serebryakov SN, Diatroptov ME. [Comparative evaluation of cytokine production by splenocytes of $\mathrm{C} 57 \mathrm{~B} / 6$ and $\mathrm{BALB} / \mathrm{C}$ mice at cold exposure]. International Journal on Immunorehabilitation. 2003;5(2):160161. [Article in Russian].

83. Sizonenko VA. Clinical evaluation and treatment of local cold trauma. Abstract of PhD Thesis. Leningrad; 1990. [In Russian].

84. Sizonenko VA, Varfolomeev AR. Bioregulatory therapy for thermal trauma. Chita: Poisk; 1999. [In Russian].

85. Shapovalov KG, Ivanov VA, Vitkovsky YuA. [IL-18 content in blood and bubble fluid in patients with local cold trauma]. Far East Medical Journal (Khabarovsk). 2008;(2):4142. [Article in Russian].

86. Gerasimov AA. The state of the resistance system of the body in healthy people and in patients with cold trauma in the Transbaikalia. Abstract of PhD Thesis. Chita; 1996. [In Russian].

87. Vikhriev BS, Kichemasov SKh, Skvortsov YuR. Local defeat by cold. L.: Meditsina; 1991. [In Russian].

88. Beaver OA, Myadelez OD, Dubovsky VV. [Dynamics of the population of mast cells during the wound process in rats subjected to hypobiotic conditions (starvation, hypothermia)]. Vestnik VSMU. 2006;5(4):21-27. [Article in Russian].

89. Ageev KV, Businaeva MT, Arzhakova LI, Garmaeva DK. [Reactive changes in lymphoid tissue of the walls of the trachea and the main bronchi under the influence of low temperatures on the human body in the Republic of Sakha (Yakutia)]. Health and Education Millennium. 2008;10(4):616-617. [Article in Russian].

90. Witkowski YuA, Kuznik BI, Solpov AV. [The phenomenon of lymphocytic-platelet rosette formation]. Immunologiia. 1999;(4):35-37. [Article in Russian].

91. Kuznik BI. Physiology and pathology of the blood system. 
Chita; 2002. [In Russian].

92. Solpov A, Shenkman B, Vitkovsky Y, Brill G, Koltakov A, Farzam N, et al. Platelets enhance CD4+ lymphocyte adhesion to extracellular matrix under flow conditions: role of platelet aggregation, integrins, and non-integrin receptors. Thromb Haemost. 2006;95(5):815-21.

93. Shapovalov KG. Pathogenetic mechanisms of local cold trauma. Abstract of ScD Thesis. Chita; 2009. [In Russian]. 94. Golokhvast KS, Celuyko SS. [Immunomodulating effect of zeolites of the Vanginskoye deposit with an inhaled administration under conditions of prolonged cooling]. Far East Medical Journal (Khabarovsk). 2006;(3):92-94. [Article In Russian].
95. Parakhonsky AP, Tsyganok SS. [Induction of apoptosis of human lymphocytes under physiological conditions]. Modern High Technologies. 2008;(9):64-65. [Article in Russian].

96. Yanchenko VV, Velichinskaya OG. [Changes of the cellular and humoral immunity in patients with cold and chronic spontaneous urticaria]. Vestnik VSMU. 2015;14(2):56-61. [Article in Russian].

97. Meshkova RY, Kovrigina NV, Vitchuk AV, Aksenova SA, Maksakova TV, Bityutskaya VV, et al. [The nature of expression of $\mathrm{CD}$ markers of lymphocytes in patients with cold and chronic spontaneous urticaria]. Allergology and Immunology (in Russian). 2016;17(3):204-207. [Article in Russian]. 